\title{
Comparative Study on the Use of Polypropylene Mesh in the Surgical Treatment of Patients with Strangulated or Uncomplicated Incisional Hernias
}

\author{
IOANA HALMACIU1', BOGDAN ANDREI SUCIU1,2*, DECEBAL FODOR ${ }^{1,2}$, DUMITRU GODJ A2, CRISTIAN TRAMBITAS', \\ VLAD VUNVULEA ${ }^{1}$, KLARA BRINZANIUC' ${ }^{1}$, CALIN MOLNAR ${ }^{2}$ \\ ${ }^{1}$ University of Medicine and Pharmacy Tirgu Mures, Anatomy Discipline, 38 Gheorghe Marinescu Str., 540142, Tirgu Mures, \\ Romania \\ ${ }^{2}$ Mures County Clinical Emergency Hospital, Surgery Clinic no.1, 50 Gheorghe Marinescu Str., 540136, Tirgu Mures, Romania
}

Incisional hernias affects approximately $10-20 \%$ of patients with history of abdominal surgery. The purpose of this study was to examine the tissue integration of the polypropylene mesh in patients operated for strangulated incisional hernias to those operated for uncomplicated incisional hernias. For this purpose, we introduced 218 patients with surgical treatment of the incisional hernia with polypropylene mesh. The total number of patients studied was divided into 2 lots: group A consisting of 189 patients with uncomplicated incisional hernia and group $B$ of 29 patients with strangulated incisional hernia. We studied separately the local postoperative complications in the two groups (hematomas, seromas, abdominal wall infections). Although the number of local postoperative complications was higher for group $B$, the differences were statistically significant only for the incidence of abdominal wall infections. Although the use of the polypropylene mesh in the surgical treatment of strangulated incisional hernias predisposes to a higher risk of local postoperative complications compared to its use in the surgical treatment of the uncomplicated incisional hernias, its use in the surgical treatment of the strangulated incisional hernias is beneficial.

Keywords : strangulated incisional hernia, polypropylene mesh

The incidence of incisional hernias in patients with a history of laparotomy is rather high. There are studies showing that approximately $10-20 \%$ of patients with a history of laparotomy will experience an incisional hernia over time. [1,2] Among the main risk factors that may lead to the occurrence of incisional hernias are: initial wound infections, obesity, and previous laborious surgery.

The occurrence of a incisional hernia in these patients may affect their quality of life, most of these patients experiencing abdominal pain that does notyield to common analgesic medication and intestinal transit disorders. One of the most common complication that may occur in these patients is the strangulation of the incisional hernia. Frequently the strangulated incisional hernia may be associated with necrosis of an intestine, which can endanger the patient's life $[3,4]$.

Taking into account the large number of postoperative complications that may occur in these patients, the vast majority of authors recommend that all patients with symptomatic or asymptomatic incisional hernias be surgically treated. As variants of surgical treatment in these patients, both classical, open and laparoscopic approaches are practiced. In the last decade, due to the development of laparoscopic surgery, more patients undergo laparoscopic approach due to the reduced number of local postoperative complications, lower morbidity and mortality compared to the open approach as well as the faster social insertion of these patients $[5,6]$.

\section{Experimental part}

The purpose of this article was to conduct a study on tissue integration of polypropylene mesh in incisional hernias patients with temporized surgical treatment and in patients with emergency surgical intervention due to diagnosis of strangulated incisional hernia. In this respect, we performed a retrospective observational study over a period of 18 months, between 1.11.2016-30.04.2018, we entered into the study 218 patients with incisional hernia operated in the Surgery Clinic no. 1 of the Emergency County Hospital Tîrgu Mure- . The data needed to carry out the study was taken from patients' observation sheets as well as from operation registers. All the patients included in this study underwent surgical treatment for incisional hernia using polypropylene mesh, which was placed supraaponeurotic (fig. 1).

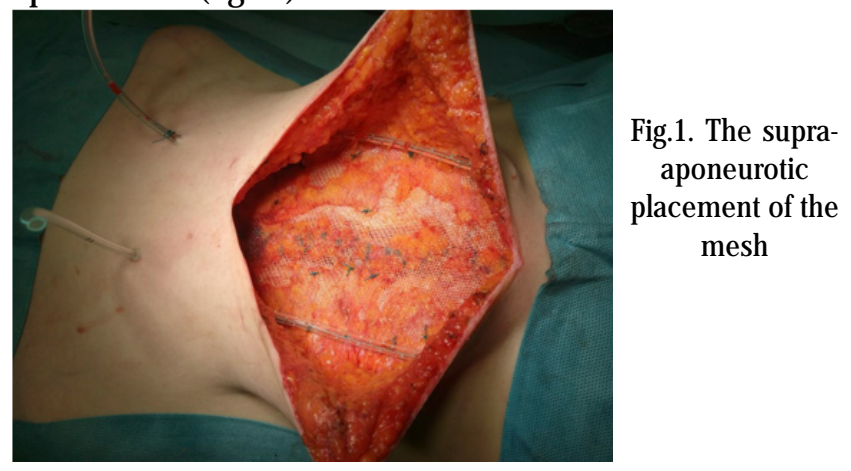

In the two lots, we studied separately the following parameters: duration of surgery, duration of hospitalization, local postoperative complications (wound infection, hematoma, seroma, surgical reinterventions). Statistical analysis of the data was done using Microsoft Excel and GraphPad Prism $7^{\circledR}$ software for this purpose using the tstudent test.

\section{Results and discussions}

The 218 patients were divided into two groups: group $A$ (189 patients with uncomplicated incisional hernias, $86.69 \%$ of cases) and group B (29 patients with

\footnotetext{
* email : suciubogdanandrei@yahoo.com, Tel : 0040744796343
} 


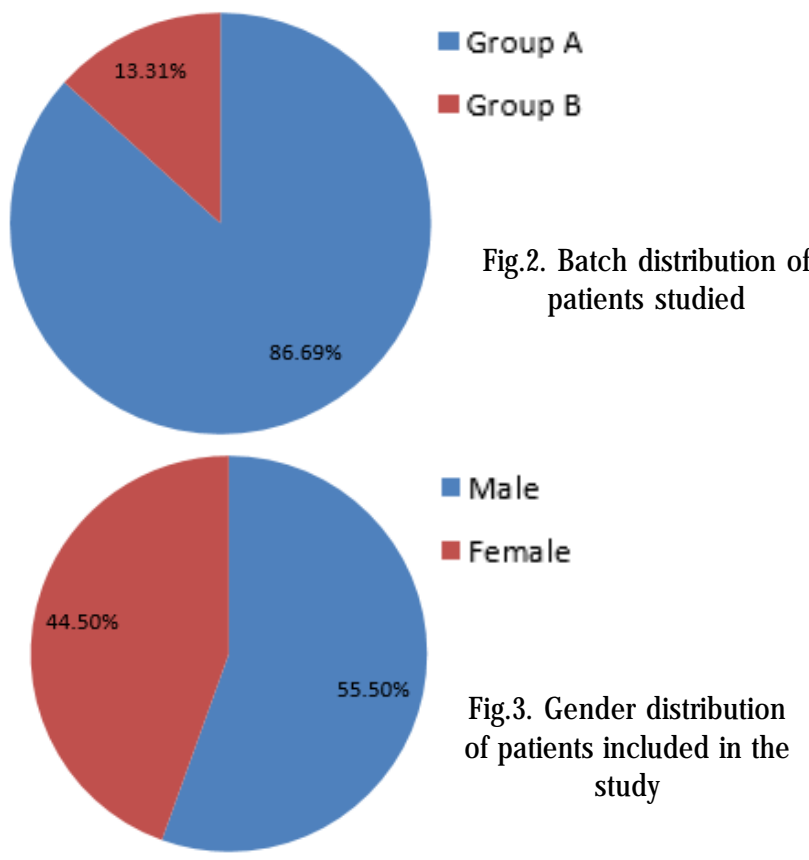

strangulated incisional hernias, $13.31 \%$ of cases). The distribution on the two lots is shown in figure 2.

In terms of gender distribution, we obtained the following results: 121 were women (55.5\% of cases) and 97 were males ( $44.5 \%$ of cases) (fig. 3). We recorded an average age of approximately 53.02 years but ranging from 23 to 86 years.

We were interested in our study about the incidence of postoperative local complications (seromas, hematomas, abdominal wall infections) in the two studied groups. For group A, 38 patients presented local postoperative complications ( $20.10 \%$ of cases) and in group B, 11 patients had postoperative local complications (37.93\% of cases). Thus, in case of group A, 18 patients presented seromas (9.52\% of cases), 12 patients had abdominal wall infections ( $6.34 \%$ of cases) and 8 patients had abdominal wall hematomas (4.23\% of cases). In group B, 4 patients had postoperative seromas ( $13.79 \%$ of cases), 6 patients had abdominal wall infections (20.68\% of cases) and 1 patient had a postoperative hematoma (3.44\% of cases) (fig. 4) The statistical analysis performed with the Fischer test showed that in the case of postoperative seromas and hematomas, there weren't statistically significant differences but in the case of abdominal wall infections the differences are statistically significant $(p=0.0426)$.

In patients with abdominal wall infections we studied separately, the number of surgical reinterventions for debridement and cleaning of the surgical wounds. Thus, we obtained the following results: in group $A$ there were 5 reinterventions ( $2.64 \%$ of cases), and in group $B$ there were 3 reinterventions ( $10.34 \%$ of cases) (fig. 5). Applying the Fischer test, the calculated $p$ value was 0.0749 , so we did not get a statistically significant difference.

From the statistical analysis using GraphPad Prism 7, by applying the t-student test, we have noticed that there is a statistically significant difference $(p<0.05)$ between the duration of the surgical interventions (measured in min) in the chronic and acute treatment of incisional hernias with a difference between means of $31.62+/-11.4$ min as seen in table 1.

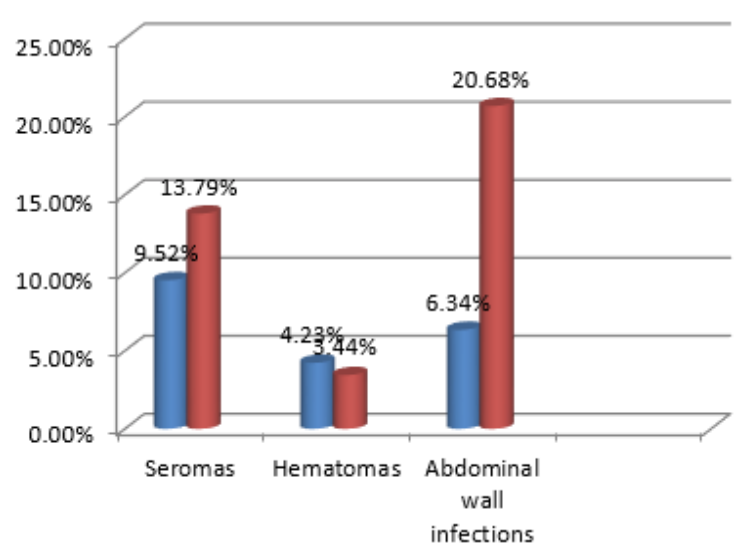

Fig 4. Local postoperative complications recorded

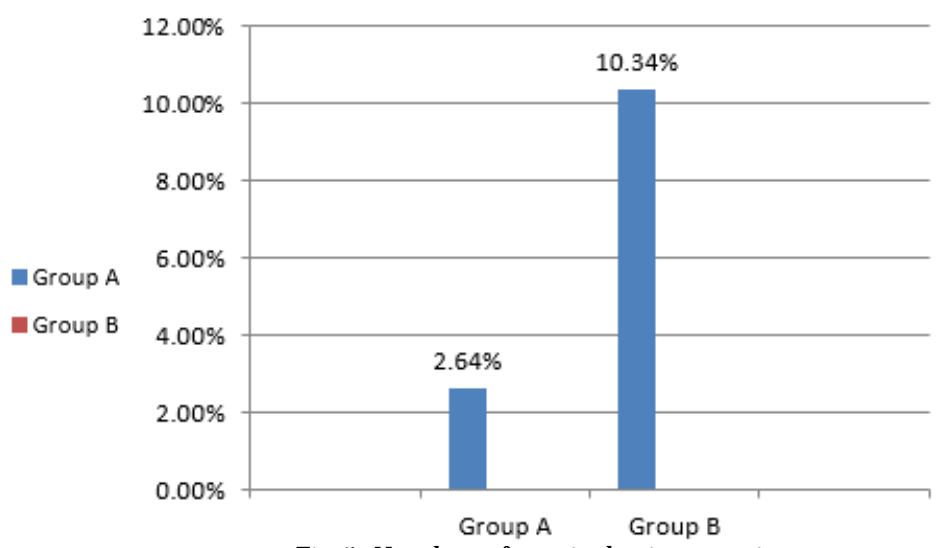

Fig 5. Number of surgical reinterventions

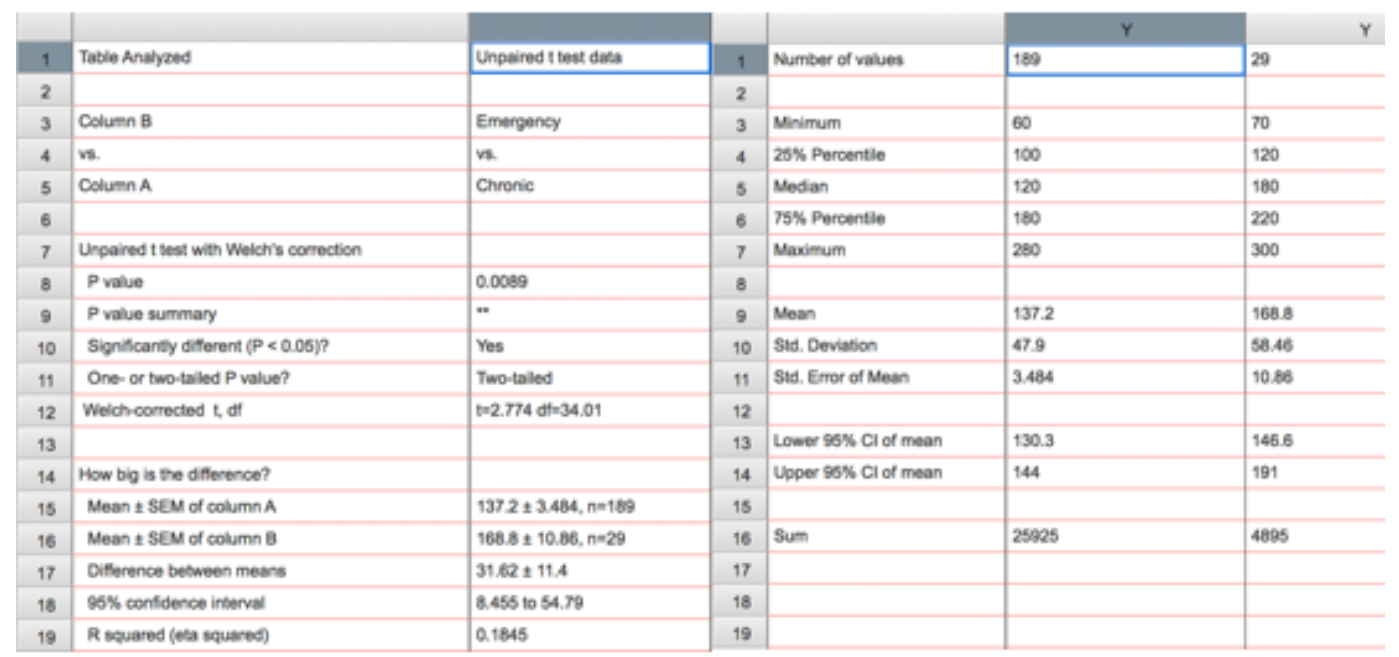

Table 1

THE STATISTICAL ANALYSIS OF THE DURATION OF THE SURGICAL INTERVENTIONS 


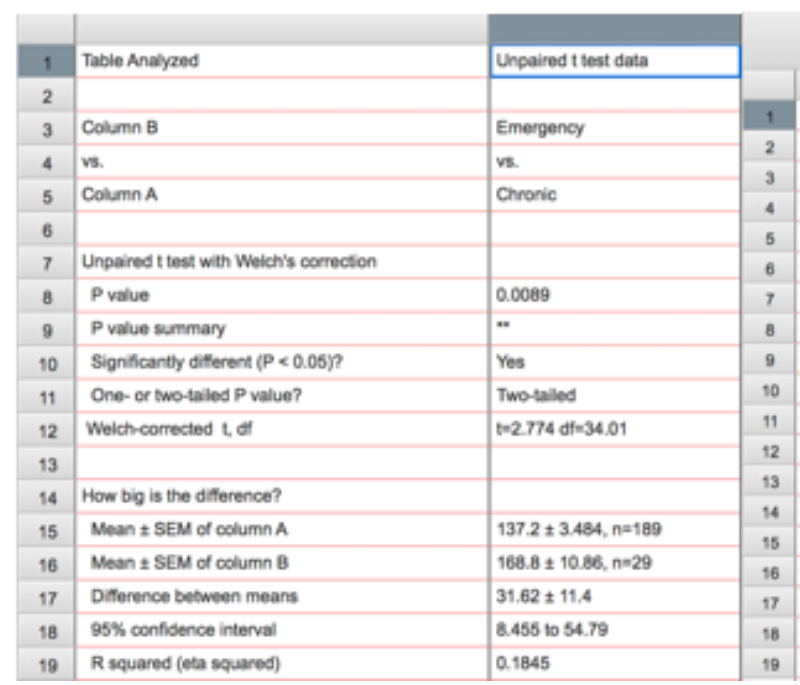

The differences in between the duration of postoperative care was also statistically different between our 2 lots, with a need of longer hospitalisation for patient who underwentemergency surgical treatment of the incisional herniass with a differences in between means of $1.69+1$ 0.56 days, as seen in table 2 .

The developing of prosthetic materials and heterologous meshes revolutionized the surgical treatment of incisional hernia. These heterologous materials are currently used both in digestive surgery and in thoracic surgery to cover various types of tissue defects and even in orthopaedics $[7,8]$. In thoracic surgery they are used in thoracic wall reconstruction techniques after thoracic wall resections for tumors, and in abdominal surgery they are used in the surgical treatment of incisional hernia and inguinal hernia $[9,10]$. Currently it is considered that the gold standard technique in the treatment of incisional hernia is the plastia of the abdominal wall with mesh [11]. Surgical meshes are also used in gynaecology in the surgical treatment of genital prolapse [12,13].

Prior to the use of heterologous meshes in the surgical treatment of incisional hernias, the rate of recurrence of such cases exceeded 40\% [14]. Currently, surgical treatment of incisional hernias using meshes can be achieved both through open, classic approach, and trough the minimally invasive laparoscopic approach. In the surgical treatment of incisional hernias through open approach, heterologous meshes may be either properitoneal, into the rectus abdominis muscle or supraaponeurotic, above the rectus abdominis muscle. There is no consensus in the literature as to which would be the best place for placement of heterologous meshes in these cases, the results of recurrence of incisional hernias and the incidence of local postoperative complications being similar. $[15,16]$ The main local postoperative complications that may occur in these cases are: hematomas, seromas, and abdominal wall infections [17].

In contrast, even if surgical treatment with prosthetic materials of incisional hernias predisposes to a higher rate of complications compared to surgical techniques in which prosthetic materials are not used, the major advantage of the former surgical techniques is given by the fact that they predispose to a much lower rate of recurrence of the postoperative eventration over time. Thus, there are literature studies that have shown that in the absence of prosthetic use in the surgical treatment of incisional hernias, the 10 -year recurrence rate can exceed $60 \%$ of the cases, and in the case of prosthetic material use is around 30\% cases [3.18].
Table 2

THE STATISTICAL

ANALYSIS OF THE

POSTOPERATIVE HOSPITALISATION TIME
At present, over 100 different types of prosthetic materials are used in the surgical treatment of incisional hernias. In this regard, both absorbable meshes and nonabsorbable meshes are used. The main characteristics that a prosthetic material has to meet in order to be used in the surgical treatment of incisional hernias are: to ensure good tissue integration as well as increased resistance of the abdominal wall in order not to predispose to the recurrence $[19,20]$. Also, the material used must be chemically inert and must produce a reduced inflammatory tissue reaction. In this regard, the vast majority of meshes used in the surgical treatment of incisional hernias and inguinal hernias exhibit pores of different sizes [21]. In this respect, it has been demonstrated that the higher the pore size, the better the biocompatibility of the net [22]. The use in clinical practice of so many different types of meshes proves that the ideal prosthetic material has not yet been discovered.

There is currently controversy over the type of mesh used in these cases. These prosthetic materials can be of three types: absorbable meshes, non-absorbable meshes, and biological meshes. Non-absorbable meshes can be made out of polypropylene, polyester or polytetra-fluoroethylene. Absorbable meshes have less use in these cases because they can not maintain over long time the resistance of the abdominal wall. They are usually used either as a temporary solution for closing the abdominal wall or in combination with a non-absorbable mesh [23,24].

The most used heterologous biological meshes in the surgical treatment of incisional hernias are those made from heterologous bovine pericardium. Heterologous bovine pericardium is a biological material that fixed in glutaraldehyde has a greatly reduced antigenicity to the human body. It is very much used in cardiovascular surgery in vascular reconstruction techniques. The major disadvantage of meshes consisting of heterologous bovine pericardium is that they are very expensive and therefore have a rather low use in the surgical treatment of incisional hernias [25].

Currently, the most common type of mesh used in open surgical treatment of incisional hernias is the polypropylene mesh $[26,27]$. One of the major advantages of this type of mesh compared to the newer generations on the market is that it has a relatively low costand that there is currently a tremendous experience in its use worldwide [28].

If, about 10 years ago, the use of prosthetic materials in the surgical treatment of incisional hernias was contraindicated, more and more authors recommend their use even in emergency surgeries performed with or without intestinal resections $[29,30]$. The authors who 
support the use of meshes in the surgical treatment of strangulated incisional hernias argue that the increased mortality and morbidity associated with these surgeries is due to the presence or absence of intestinal necrosis and notdue to the use of the mesh itself; and the risk of infection of the abdominal wall is relative low, being less than $10 \%$ of cases [31-33]. This rather low rate of abdominal wall infections can be prevented by introducing wide-spectrum antibiotics for the length of the postoperative period [34].

\section{Conclusions}

Although the use of the polypropylene mesh in the surgical treatment of strangulated incisional hernias predisposes to a higher number of local postoperative complications compared to its use in the surgical treatment of the uncomplicated incisional hernias, the overall results are beneficial and recommended.

\section{References}

1.KINGSNORTH A., LEBLANC K., Lancet., 362,2003,nr.9395,p.15611571

2.SEVINC B., OKUS A., AY S., AKSOY N., KARAHAN O., Turk. J. Surg., 34,2018,nr.1,p.17-20

3.BURGER JW., LIUJ ENDIJ K RW., HOP WC., HALM JA., VERDAASDONK EG., JEEKEL J., Ann. Surg., 240,2004,nr.4,p.578-583

4.CASSAR K., MUNRO A., Br. J. Surg., 89, 2002, nr.5, p.534-545

5.WARREN JA., LOVE M., Surg. Clin. North. Am., 98,2018,nr.3,p.537559

6.TSUJ INAKA S., NAKANAYASHIY., KAKIZAWA R., TOYAMA N., RIKIYAMA T., 21,2018,P.14-18

7.MURESAN M., MURESAN S., BARA T., BRINZANIUC K., SALA D., SUCIU B., RADU N., Ann. Ital. Chir., 86,2015,p.421-426

8.TRAMBITAS, C., POP, TS., TRAMBITAS MIRON, A.D., DOROBANTU, D.C., BRINZNIUC, K., Rev. Chim.(Bucharest), 68, no. 2, 2017, p.387 9.BUD V., SUCIU BA., BUTIURCA V., BRINZANIUC K., COPOTOIU R., COPOTOIU C., SIN A., Rom. J. Morphol. Embryol., 54,2013,nr.1,p.115119

10.SUCIU, B.A., HALMACIU, I., BUD, V., COPOTOIU, C., FODOR, D.R.P., TRAMBITAS, C., VUNVULEA. V., MOLNAR, C., BRINZANIUC, K., Mat. Plast. 54, no. 3, 2017, p.520-522

11.VOELLER GR., RAMSHAW B., PARK AE., HENIFORD BT., J. Am. Coll. Surg., 189,1999,nr.6,p.635-637

12.SUCIU, BA., HALMACIU, I., BUD, V., COPOTOIU, C., FODOR, D., TRAMBITAS, C., GODJA, D., VUNVULEA, V., MOLNAR, C., BRINZANIUC, K., Mat. Plast. 54, no. 4, 2017, p.626-629

13.SUCIU, BA., PAP, Z., DENES, L., BRINZANIUC, K., COPOTOIU, C., PAVAI Z., Rom. J. Morphol. Embryol., 57,2016,nr.2,p.495-500
14.SAUERLAND S., SCHMEDT CG., LEIN S., LEIBL BJ., REINHARD BITTNER R., Langenbecks. Arch. Surg., 390,2005,nr.5,p.408-412

15.VIDOVIC C., JURISIC D., FRANJIC BD., GLAVAN E., LEDINSKY M., BESLIN MB., Hernia, 10,2006,nr.4,p.322-325

16.GLEYSTEEN J ., Arch. Surg., 144,2009,nr.8,p.740-745

17.BASOGLU M., YILDIRGAN MI., YILMAZ I., BALIK A., CELEBI F., ATAMANALP SS., POLAT KY., OREN D., Acta. Chir. Belg., 104,2004,nr.4,p.425-428

18.PLENCNER M., PROSECKA E., RAMPICHOVA M., EAST B., BUZGO M., VYSLOUZILOVA L., HOCH J., AMLER E., Int. J. Nanomedicine., 1,2015,nr.10,p.2635-2646

19.SHANKARAN V., WEBER DJ ., REED RL 2ND, LUCHETTE FA., Ann. Surg., 253,2011,nr.1,p.16-26

20.EBERSOLE GC., BUETTMANN EG., MACEWAN MR., TANG ME., FRISELLA MM., MATTHEWS BD., DEEKEN CR., Surg. EndosC., 26,2012,nr.10,p.2717-2728

21.SATO S., CHEN G., USHIDA T., ISHII T., OCHIAI N., TATEISHI T., TANAKA J., Mater. Sci. Eng. C. Mater. Biol. Appl., 24,2004,nr.3,p.365372

22.SCHEIDBACH H., WOLFF S., LIPPERT H., Zentralbl. Chir., 136,2011,nr.6,p.568-574

23.KLINGE U., KLOSTERHELFEN B., Hernia., 16,2012,nr.3,p.251-258 24.CODA A., LAMBERTI R., MARTORANA S., Hernia., 16,2012,nr.1,p.920

25.BURGER JW., HALM JA., WIJ SMULLER AR., TEN RAA S., JEEKEL J., Sur. Endosc., 20,2006,nr.8,p.1320-1325

26.VASILE, D., IANCU, G., IANCU, R.C., DAVITOIU,D.V., Mat. Plast.,54, no. 2, 2017, p.229

27.BRATU, D., BOICEAN, A., TANASESCU, C., SOFARIU, C., MIHETIU, A., CERNUSCA MITARIU, I.S.., OGNEAN, L., MOLDOVAN, C., BOITOR, C., Mat. Plast., 54, no. 1, 2017, p.119

28.UDO IA., ONWUEZOBE IA., UMEH KU., Niger. J. Surg., 24,2018,nr.1,p.19-22

29.OZBAGRIACIK M., BAS G., BASAK F., SISIK A., ACAR A., KUDAS I., YUCEL M., OZPEK A., ALIMOGLU 0., North. Clin. Istanb., 2,2015,nr.1, p.26-32

30.DERICI H., UNALP HR., NAZLI O., KAMER E., COSKUN M., TANSUG T., BOZDAG AD., Langenbecks. Arch. Surg., 395,2010,nr.5,p.575-579

31.NIEUWENHUIZEN J., VAN RAMSHORTS GH., TEN BRINKE JG., DE WIT T., VAN DER HARST T., HOP WC., J EEKEL J., LANGE J F., Hernia., 15,2011,nr.3,p.297-300

32.LEGANI GL., RASINI M., PASTORI S., SARLI D., Hernia., 12,2008,nr. 2,p.185-188

33.BESSA S., KATRI KM., ABDEL-SALAM W N., ABDEL-BAKI NA., Hernia., $11,2007, n r .3, p .239-242$

34.YERDEL MA., AKIN EB., DOLALAN S., TURKCAPAR AG., PEHLIVAN M., GECIM IE., KUTERDEM E., Ann. Surg., 233,2001,Nr1,p.26-33

Manuscript received: 7.02 .2108 